\title{
Proses Memaafkan dalam Konteks Agama Islam pada Remaja yang Orang Tuanya Bercerai
}

\author{
ARIADNE A. TRIANGGONO* \& DANNY I. YATIM \\ Universitas Katolik Indonesia Atma Jaya
}

\begin{abstract}
ABSTRAK
Memaafkan adalah perubahan prososial yang dialami terhadap pelaku, meliputi penurunan motivasi menghindari kontak pribadi dan psikologis, penurunan motivasi membalas dendam, dan peningkatan motivasi kebajikan terhadap pelaku. Empat fase proses memaafkan meliputi; uncovering, decision, work, dan deepening. Remaja tengah (usia 15-18 tahun) berada pada tahap 3 perkembangan memaafkan, yaitu expectational forgiveness. Penelitian bertujuan menggambarkan proses memaafkan dalam konteks Islam pada remaja yang orang tuanya bercerai, menggunakan pendekatan kualitatif dengan desain fenomenologi dengan wawancara semi-terstruktur. Partisipan yang diambil adalah tiga remaja usia tengah, laki-laki, orang tuanya bercerai, beragama Islam, dan menyalahkan ayah. Hasil penelitian ini menunjukkan agama Islam berkontribusi terhadap proses memaafkan yang dilakukan partisipan. Kemudian, pengalaman menyakitkan yang perlu dimaafkan remaja berkaitan dengan apa yang dilakukan oleh ayah sebelum atau setelah perceraian. Dari proses tersebut, ketersediaan memaafkan ketiga remaja menunjukkan tahap 4 perkembangan; lawfully expectational forgiveness. Selanjutnya, proses memaafkan remaja cukup berkaitan dengan kualitas hubungan dengan ayah.
\end{abstract}

Kata kunci: anak, islam, memaafkan, perceraian, remaja

\begin{abstract}
Forgiving is person's prosocial change whereas the one who becomes less motivated is inclined to avoid personal and psychological contact with the offender, less motivated to retaliate against the offender, and more motivated by goodwill for the offender. There are four phases in the process of forgiveness: uncovering, decision, work, and deepening. Middle adolescents (aged 15-18 years old) tend to be in stage 3 of forgiveness development: expectational forgiveness. This study aimed to describe the process of forgiveness of adolescents with divorced parents in the context of Islam, carried out with the phenomenological design of qualitative approach and semi-structured interviews. The participants were three male middle adolescents, with divorced parents, Muslims, blaming the father for the divorce. The results of this study show, Islam contributes to the process of forgiveness. Moreover, the painful experience that needs to be forgiven itself has more to do with what the father did before or after the divorce. However, from the process of forgiveness, the willingness of forgiving from the three adolescents tend to be in stage 4 development; lawfully expectational forgiveness. In addition, the process of forgiveness of adolescents is quite related to the quality of relationships with fathers.
\end{abstract}

Key words: adolescence, children, divorce, forgiving, Islam 
INSAN Jurnal Psikologi dan Kesehatan Mental, 2020, Vol. 5(2), 71-87, doi: 10.20473/jpkm.v5i22020.88-111 Dikirimkan: 17 Desember 2019 Diterima: 23 Maret 2020 Diterbitkan: 2 November 2020 Editor: Rizqy Amelia Zein

*Alamat korespondensi: Jalan Jenderal Sudirman 51, Jakarta 12930 Pos-el: ariadne.ayuningtyas@gmail.com

Naskah ini merupakan naskah dengan akses terbuka dibawah ketentuan the Creative Common Attribution License (http://creativecommons.org/licenses/by-sa/4.0), sehingga penggunaan, distribusi, reproduksi dalam media apapun atas artikel ini tidak dibatasi, selama sumber aslinya disitir dengan baik.

\section{PEN D A H U L UA N}

Memaafkan atau forgiveness adalah fenomena yang amat terkait dalam menjelaskan kesejahteraan seseorang (Toussaint, Worthington, \& Williams, 2015). Memaafkan dikaitkan dengan berbagai manfaat kesehatan mental termasuk mengurangi stres, kemarahan, depresi, dan kecemasan; kesehatan relasional yang positif termasuk peningkatan dukungan sosial dan kualitas pernikahan, dan berbagai manfaat kesehatan fisik termasuk menurunkan tekanan darah, dan meningkatkan kesehatan kardiovaskular (Worthington \& Drinkard, 2000).

Memaafkan adalah perubahan prososial dalam motivasi interpersonal yang seseorang alami terhadap pelaku (seseorang yang telah dianggap menyakiti), yang meliputi penurunan motivasi untuk menghindari kontak pribadi dan psikologis dengan pelaku, penurunan motivasi untuk membalas dendam kepada pelaku, dan peningkatan motivasi terhadap kebajikan (McCullough, Worthington, \& Rachal, 1997). Di dalam definisi ini, McCullough dkk. (1997) menempatkan motivasi sebagai inti dari definisinya, kemudian melihatnya sebagai perubahan yang sifatnya proposional dalam motivasi interpersonal. Hal ini kemudian berarti memaafkan adalah proses yang sifatnya interpersonal.

Enright, Freedman, \& Rique, (1998) menyebutkan bahwa ada empat langkah dalam proses memaafkan. Pertama, uncovering the phase atau saat-saat mengalami kejadian yang menyakitkan dan berulangulang memikirkannya. Kedua, decision phase atau ketika mendapat insight mengenai pentingnya memaafkan kemudian memutuskan untuk memaafkan. Ketiga, work phase, atau ketika mencoba memahami dan berempati pada pelaku, kemudian melakukan pemaafan. Keempat, deepening phase, atau ketika merasakan maanfaat dari memaafkan, kemudian menemukan makna baru dalam membangun hubungan.

Ada hal penting yang perlu disoroti dalam setiap proses memaafkan kesalahan orang tua yang dilakukan oleh anak-anaknya. Proses memaafkan tidak dipandang sebagai "urutan langkah yang kaku, tapi serangkaian proses yang fleksibel dengan langkah maju dan langkah mundur" (Enright dkk., 1998). Hal ini memungkinkan untuk setiap orang melewati satu proses atau kembali dan melakukan kembali proses yang pernah dialami. Selain itu, memaafkan memerlukan waktu yang berbeda-beda pada masing-masing orang.

Penelitian ini akan berfokus pada memaafkan yang dilakukan oleh remaja. Enright, Santos, \& Al-Mabuk, (1989), dalam penelitiannya, menjelaskan tahapan perkembangan memaafkan yang mengadopsi teori perkembangan moral Kohlberg secara langsung (1976, dalam Enright, Santos, \& Al-Mabuk, 1989). Dalam penelitian ini, Enright, dkk. (1989) menyatakan secara khusus bahwa remaja sebagian besar berada pada tahap ketiga dari perkembangan memaafkan, yaitu tahap expectational forgiveness. Dalam

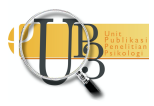


tahap ini, remaja mempersepsikan memaafkan sebagai "Saya bisa memaafkan jika orang lain memberi tekanan pada saya untuk memaafkan. Lebih mudah memaafkan bila orang lain mengharapkannya". Selain itu, Paleari, Regalia, dan Fincham, (2003) dalam penelitiannya menunjukkan bahwa kemauan untuk memaafkan yang dilakukan sebagian besar remaja bergantung pada kualitas hubungan mereka dengan pelaku.

Salah satu hal yang dapat melibatkan proses memaafkan bagi remaja ialah perceraian orang tua. Menurut Dewi (2006) dalam penelitiannya, perceraian orang tua dimaknai anak, dalam hal ini remaja, sebagai kejadian yang tidak menyenangkan dan menyakitkan mereka. Ketika seseorang merasa disakiti, dirugikan, atau diperlakukan tidak adil oleh orang lain, maka kesejahteraan emosinya dapat terganggu. Oleh sebab itu, remaja menjadi marah akibat perceraian orang tua sekaligus pada orang tua yang dianggap menyebabkan perceraian. Lebih lanjut, dampak perceraian berkaitan dengan penghayatan rasa sakit yang remaja rasakan. Remaja merasa sakit, terutama terhadap orang tua mereka akibat adanya pengalaman yang menyakitkan yang mereka hayati akibat perceraian orang tua mereka. Adanya rasa sakit tersebut membuat remaja mungkin mempertimbangkan memaafkan sebagai pilihan dan melalui prosesnya.

Perceraian sendiri menurut Undang-Undang Republik Indonesia No.1 tahun 1974 (pasal 16) terjadi apabila antara suami-istri yang bersangkutan tidak mungkin lagi didamaikan untuk hidup rukun dalam suatu rumah tangga. Perceraian terjadi terhitung pada saat perceraian itu dinyatakan di depan sidang pengadilan (pasal 18). Gugatan perceraian dapat diajukan oleh suami atau istri atau kuasanya pada pengadilan dengan alasan-alasan yang dapat diterima oleh pengadilan yang bersangkutan. Undang Undang Perkawinan, 1974 Bab VIII, pasal 39 ayat 2 berbunyi: "Untuk melakukan perceraian harus ada cukup alasan antara suami istri untuk tidak akan hidup rukun sebagai suami istri”. Menurut Undang Undang Perkawinan No. 1/1974, perceraian adalah keadaan terputusnya suatu ikatan perkawinan.

Perceraian menurut (Corsini, 2010) adalah pemutusan hubungan pernikahan yang dilakukan secara legal (di bawah keputusan hukum). Sebelum dilakukan pemutusan hubungan pernikahan ini, biasanya sudah terjadi konflik-konflik yang tidak dapat terselesaikan, atau tindakan yang saling menyakiti di antara pasangan sehingga kedua belah pihak merasa perlu untuk melakukan perceraian. Hal ini dilakukan untuk mengakhiri hal-hal yang tidak menyenangkan tersebut di antara kedua belah pihak yang sudah dan mungkin akan kembali terjadi ke depannya.

Amato (1993) dalam artikelnya mengenai adaptasi anak pada perceraian orang tua, menyatakan bahwa ada enam hal utama penyebab kesulitan anak akibat perceraian orang tua dibandingkan dengan anak yang tidak mengalami perceraian orang tua. Hal tersebut meliputi; kehilangan orang tua, kesulitan ekonomi, stres yang berlebih, penyesuaian orang tua yang buruk, kurangnya kompetensi orang tua dalam mengasuh, dan eksposur terhadap konflik interparental. Di samping itu, di dalam DSM V (2013), dijelaskan bahwa dampak perceraian pada anak dapat menjadi fokus klinis yang perlu ditangani, yaitu sebagai masalah yang berkaitan dengan tahap perkembangan atau masalah yang berkaitan dengan lingkungan kehidupan seseorang (anak).

Dalam hal ini, memaafkan dapat memainkan peran penting dalam keluarga ketika satu anggota keluarga mengalami luka yang ditimbulkan oleh anggota lain (Enright dkk., 1998). Selain itu, Setyawan (2007) mengungkapkan bahwa memaafkan sangat dibutuhkan bagi anak (dalam hal ini remaja) untuk mengelola dan menanggulangi distres yang dirasakan. Rangkaian yang diberikan oleh proses pemaafan dapat mengarahkan anak untuk menekankan jalur damai dan cinta kasih, untuk mengatasi rasa sakit

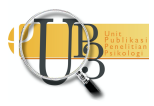


yang dirasakan. Anak kemudian tidak lagi menimpakan beban kesalahan pada orang lain (dalam hal ini orang tua) dan dapat melihat bahwa terdapat hal yang lebih penting yaitu berusaha untuk mencapai perasaan dan kondisi damai itu sendiri. Dengan melakukan pemaafan, anak mampu menggunakan sensitivitas pribadi dan sosialnya untuk mengatasi halangan untuk melakukan pemaafan dan menolak balas dendam sebagai pemecahan masalah. Kemudian McCullough, dkk. (1997) menyatakan bahwa dengan meningkatnya jumlah stres, kekerasan, kemarahan, dan perselisihan, memaafkan dapat mencegah masalah dan meningkatkan kesejahteraan.

Agama Islam memiliki konsep yang berbeda mengenai memaafkan. Di dalam Al-Quran, Kitab Suci agama Islam (Nimer, 2013 dalam Muntafi, 2014), secara umum dijelaskan bahwa memaafkan dapat dikategorikan menjadi dua bagian, yaitu (1) memaafkan oleh Allah SWT dan (2) memaafkan oleh manusia. Secara singkat, proses meminta maaf yang perlu dilakukan oleh seseorang jika telah menyakiti orang lain meliputi dua bagian di atas. Pertama, orang tersebut perlu meminta maaf pada Allah. Kedua, orang yang tersebut juga perlu meminta maaf pada orang yang telah disakiti. Dengan kata lain, seseorang dianggap memaafkan jika telah dimaafkan oleh Allah dan orang yang disakiti.

Di dalam Islam, memaafkan (oleh manusia) bukanlah sebuah kewajiban. Memaafkan merupakan sebuah pilihan atau hak seseorang, meskipun Islam lebih menekankan meminta maaf sebagai sebuah kewajiban. Ketika didzalimi seseorang berhak untuk membalas dengan balasan atau hukuman yang setimpal. Kendati demikian, Islam mengajarkan untuk mengambil sikap memaafkan sebagai sikap yang mulia. Hal ini tercantum dalam Al-Quran surat Asy-Syura: 39-40. Ayat tersebut menunjukkan pentingnya memahami memaafkan bukan sebagai sebuah kelemahan. Sikap memaafkan perlu dipahami terlebih dahulu dalam konteks agama Islam, sehingga tidak terjebak pada kesalahan pengertian bahwa memaafkan membuat korban menjadi lemah (Nimer, 2013 dalam Muntafi, 2014)).

Penelitian sebelumnya yang serupa pernah diteliti oleh Dewi (2006). Metode penelitian yang dipergunakan adalah metode kualitatif dengan tipe fenomenologi. Partisipan yang diambil dalam penelitian ini berjumlah empat orang dengan karakterisitik remaja berusia 11-24 tahun yang orang tuanya bercerai dengan rentang waktu 2-10 tahun, keempat partisipan secara tidak sengaja beragama Kristen, dan tinggal bersama dengan salah satu orang tuanya. Hasil dari penelitian ini menunjukkan bahwa partisipan remaja yang orang tuanya bercerai dapat melihat makna dan sisi positif dan peceraian orang tuanya. Kemudian, waktu perceraian tidak berkaitan dengan kemampuan seseorang dalam memaafkan. Partisipan mengalami dampak perceraian yang beragam.

Dalam penelitian yang dilakukan Dewi (2006), terdapat hal yang menarik ditelusuri lebih jauh. Secara tidak sengaja keempat partisipan memiliki latar belakang agama Kristen yang cukup kuat dan nampak sangat berkaitan dengan dinamika proses memaafkan partisipan. Tiga dari empat partisipan menyatakan bahwa ajaran ke-Kristenan mengajarkan mereka untuk mengasihi (dalam hal ini orang tua), dan juga adanya rencana Tuhan dalam setiap kejadian, sehingga lebih mampu memaafkan. Selain itu, tiga dari empat partisipan tersebut terlibat dalam komunitas Kristen sebagai tempat berbagi terutama dalam peristiwa menyakitkan. Terdapat diskusi seirama yang dikemukakan oleh Worthington (2005) dalam bukunya, mengenai bagaimana dan untuk siapa memaafkan berhubungan dengan agama. Worthington menyatakan bahwa bukan hanya karena metode ilmiah yang selama ini digunakan sebagai metode untuk mempelajari memaafkan, bukan berarti memaafkan dapat dipisahkan dari sisi agama. Selama berabad-abad, memaafkan telah dikaitkan dengan agama-agama besar (Rye, dkk dalam Worthington, 2005) dan paling terpusat pada agama Kristen (Marty dalam Worthington, 2005). 
Konsep psikologi mengenai memaafkan dalam keluarga yang dikaitkan dengan agama Islam belum banyak dikaji di Indonesia, sehingga kaitan agama Islam terhadap memaafkan, khususnya dalam keluarga, masih dipertanyakan seperti yang disebutkan oleh Worthington (2005) mengenai bagaimana dan pada siapa agama berpengaruh pada proses memaafkan. Hal ini tergambar dari sedikitnya publikasi jurnal ataupun buku psikologi mengenai memaafkan dalam keluarga yang ditulis oleh ilmuwan yang berusaha mengupas dari sudut pandang agama Islam di Indonesia.

Penelitian ini berusaha menggambarkan proses memaafkan remaja yang orang tuanya bercerai dari sudut pandang agama, secara khusus agama Islam. Dalam kitab suci umat Muslim, yaitu Al-Quran dan Hadist, banyak dimuat konsep memaafkan. Kajian mengenai memaafkan juga banyak ditemukan dalam buku-buku akhlak yang membahas mengenai kemuliaan Nabi Muhammad SAW dalam memaafkan, akan tetapi, belum banyak yang berusaha mengangkat konsep psikologi memaafkan berdasarkan perspektif agama Islam sehingga penelitian ini perlu dilakukan sekarang. Adapun tujuan dari penelitian ini, yaitu: menggambarkan: menggambarkan proses memaafkan remaja yang orang tuanya bercerai dalam konteks agama Islam.

\section{E T O D E}

\section{Desain Penelitian}

Penelitian ini menggunakan metode kualitatif, mulai dari gagasan dan ide penelitian, mengumpulkan data, menjawab permasalahan, dan tujuan penelitian melakukan kategorisasi. Menurut Creswell (2012), penelitian kualitatif adalah jenis penelitian dimana peneliti sangat tergantung terhadap informasi dari objek/partisipan pada: ruang lingkup yang luas, pertanyaan yang bersifat umum, pengumpulan data yang sebagian besar terdiri atas kata-kata/teks dari partisipan, menjelaskan dan melakukan anislis tehadap kata-kata, dan melakukan penelitian secara subjektif. Tipe penelitian kualitatif yang digunakan adalah fenomenologi. Tipe fenomenologi digunakan karena di dalamnya peneliti berusaha mengidentifikasi tentang suatu fenomena tertentu, serta mengharuskan peneliti mengkaji partisipan dengan terlibat langsung untuk mengembangkan pola dan relasi yang bermakna (Creswell, 2012).

\section{Partisipan}

Terdapat kriteria untuk menentukan partisipan dalam penelitian ini, yang meliputi: Remaja tengah dengan batasan usia 15-18 tahun, mengacu pada Enright, Santos, dan Al-Mabuk (1989), dalam teori pekembangan memaafkan yang menyatakan bahwa remaja dengan usia 15-18 tahun mendekati atau sedang ada pada tahap 3 memaafkan: expectational forgiveness, orang tuanya bercerai menurut hukum, dan beragama Islam.

Partisipan dalam penelitian ini diambil dengan menggunakan teknik purposive sampling atau tidak secara acak. Jenis purposive sampling yang digunakan dalam penelitian ini adalah homogeneous sampling. Dalam homogeneous sampling, peneliti sengaja mengambil partisipan berdasarkan keanggotaan dalam subkelompok yang memiliki karakteristik yang ditentukan (Creswell, 2012). Pada penelitian ini, peneliti memilih paritispan tertentu karena mereka memiliki karakteristik yang serupa. Partisipan yang berhasil diambil ialah tiga remaja laki-laki, berusia 16-18 tahun, beragama Islam, orang tuanya bercerai, menyalahkan ayah atas perceraian orang tua, dan tinggal bersama ibu.

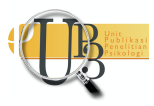




\section{Teknik Pengumpulan Data}

Teknik pengumpulan data dalam penelitian ini adalah wawancara. Peneliti kemudian mentranskripsikan dan mengetikkan data ke dalam file komputer untuk dianalisis (Creswell, 2012). Jenis wawancara yang dilakukan adalah one on one interview, yaitu proses pengumpulan data dimana peneliti mengajukan pertanyaan dan mencatat jawaban hanya dari satu partisipan dalam studi ini pada satu waktu dan melibatkan in-depth interview atau wawancara mendalam. Seringkali beberapa wawancara dilakukan dengan masing-masing peserta penelitian (Creswell, 2007).

Panduan wawancara yang peneliti susun berisi sejumlah poin pertanyaan yang dapat digunakan peneliti sebagai acuan dalam memberikan pertanyaan dan membentuk alur wawancara. Jenis panduan pertanyaan yang digunakan oleh peneliti ialah semi-terstuktur, sehingga peneliti dapat menggali lebih dalam temuan-temuan baru yang diucapkan oleh partisipan. Panduan wawancara dibagi menjadi ketiga bagian, yang meliputi: panduan wawancara latar belakang partisipan, keluarga, dan perceraian orang tua; panduan wawancara proses memaafkan menggunakan definsi oleh McCullough dkk., 1997), kemudian fase serta tahapan memaafkan dari Enright dkk., (1998) sebagai domain dan indikator pertanyaan.

\section{Analisis Data}

Metode analisis data dalam penelitian ini menggunakan teknik tematik. Menurut Creswell (2012), terdapat enam langkah yang terlibat dalam menganalisis dan menginterpretasi data kualitatif menggunakan teknik tematik, yang meliputi: (1) mempersiapkan dan mengatur data untuk dianalisis, (2) menjelajahi dan mengode data, (3) pengodean dan membangun deskripsi data \& tema, (4) mewakili dan melaporkan temuan kualitatif, (5) menginterpretasi temuan, dan (6) validasi akurasi temuan. Dalam penelitian ini, penelitian menggunakan metode uji validitas member checking. Member checking adalah proses di mana peneliti meminta satu partisipan dalam penelitian untuk memeriksa keakuratan data. Pemeriksaan ini melibatkan pengambilan kembali temuan kepada peserta dan meminta mereka tentang keakuratan laporan (Creswell, 2012).

\section{HAS I L P E N E L I T I A N}

\section{Partisipan 1}

Yanda (bukan nama sebenarnya) merupakan seoarang remaja laki-laki berusia 16 tahun dan sedang menempung pendidikan di Jakarta kelas dua SMA. Yanda sendiri merupakan keturunan bersuku Jawa, namun menetap di Jakarta sejak lahir. Yanda sendiri memeluk agama Islam, seperti agama yang dipeluk oleh ayahnya.Yanda merupakan anak pertama dari empat bersaudara, buah dari perkawinan ayahnya, dan ibunya. Kedua ayah dan ibu Yanda bersuku Jawa, namun keduanya menganut agama yang berbeda. ayahnya menganut agama Islam bersama Yanda, adik kedua, dan adik ketiga Yanda, sedangkan ibunya dan adik kedua Yanda memeluk agama Kristen.

Mengenai penerapan ajaran agama Islam di keluarga, Yanda mengaku ayahnya lah yang paling memegang peran, sebab ibunya sendiri bukan seorang Muslim. Yanda menjelaskan, ajaran agama yang diberikan sama seperti kebanyakan keluarga lain, yaitu salat 5 waktu, salat Jumat, mengaji (membaca 
Al-Quran), berpuasa, dan berzakat. Bahkan, ayah Yanda mewajibkan anak-anaknya untuk bangun pagi untuk salat Subuh berjamaah.

Perceraian orang tua Yanda terjadi saat Yanda berusia kurang lebih 12 tahun, saat ia berada pada bangku kelas enam SD. Pada saat ini perceraian orang tua Yanda sudah berusia lima tahun. Pernikahan orang tua Yanda terhitung dari menikah sampai bercerai berusia 13 tahun. Perceraian orang tua Yanda disebabkan karena perbedaan agama ayah dan ibu Yanda, yang kemudian membuat adanya perbedaan keinginan dari pada anak. Yanda menganggap, ayahnya ingin anak-anaknya memeluk agama Islam, dan ibunya menginkan anak-anaknya memeluk agama Kristen. Kendati demikian, ibu Yanda telah rela keempat anak-anaknya beragama Islam.

\section{Gambaran Umum Proses Memaafkan}

\section{Uncovering phase}

Menelaah ulang pertahanan psikologis diri. Defense mechanism yang digunakan oleh pertama-tama ialah denial. Perasaan yang menggambarkan Yanda saat itu ialah sedih dan hancur. Yanda merasa bingung harus melakukan apa, terlebih lagi jika ia melihat adik-adiknya, meski adik-adiknya masih terbilang kecil. Yanda merasa sangat terpukul atas perceraian orang tuanya, namun dalam lubuk hatinya, Yanda merasa memang terdapat hal yang kurang dari kedua orang tuanya sebagai pasangan. Hal yang kurang ialah kebersamaan dan keterjagaan satu sama lain.

Mengkonfrontasi rasa marah. Dari perceraian orang tuanya, Yanda merasa sangat marah. Kendati demikian, Yanda tidak pernah menungkapkan rasa marahnya secara langsung pada orang tuanya. Yanda justru jadi membantah perkataan orang tuanya dan merasa lebih baik menghindar. Meski begitu, terdapat perbedaan sikap yang ditunjukkan Yanda pada ayah dan ibunya. Dalam hal ini, Yanda merasa lebih marah terutama pada ayahnya. Ia merasa ayahnya lah yang bersalah karena dengan mudahnya meninggalkan ibunya untuk kembali menikah.

Mengakui rasa malu atau rasa bersalah. Dengan kondisi keluarga yang sudah bercerai dan ayahnya yang sudah menikah kembali, Yanda sama sekali tidak merasa malu ataupun merasa bersalah. Muncul kesadaran akan kesadaran akan katarsis. Perceraian mempengaruhi beberapa aspek dalam kehidupan Yanda, yaitu fisik (mudah sakit), akademis (performa dan semangat menurun), dan emosi (mudah marah).

Muncul kesadaran yang berulang mengenai hal yang menyakitkan. Yanda mengaku tidak terlalu banyak memikirkan kejadian perceraian orang tuanya. Ia mengaku memikirkan kejadian perceraian sesekali. Jika sudah memikirkan, efeknya bisa sampai mengganggu kesehatan. Pada Yanda, tahap ini tidak terjadi begitu terasa, sebab Yanda mengaku tidak terlalu banyak memikirkan perceraian orang tuanya. Pikiran tentang perceraian hanya muncul sesekali, dan ketika memikirkannya, kondisi fisiknya terpengaruh.

Mendapatkan insight dengan membandingkan diri dengan pelaku. Yanda mengaku tidak pernah mencoba memosikan diri sebagai ayah. Namun ketika ditanya mengenai bagaimana perasaannya melihat ayahnya yang kini telah memiliki pasangan yang satu iman, Yanda mengaku tidak senang melihat ayahnya menikah dengan perempuan lain, sebab seharusnya yang menjadi istrinya ialah ibu. Sadar bahwa diri sendiri dapat berubah secara permanen dan negatif akibat rasa sakit tersebut. Dari sisi hubungannya dengan teman, Yanda merasa menjadi lebih pendiam, berbeda dengan dirinya saat kecil yang aktif. Pada awalnya, alasan dari sifatnya pendiam sebab ia merasa masih belum percaya

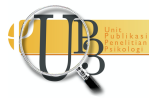


dengan keadaan keluarganya yang sudah terpisah, dan hal tersebut membuatnya jadi lebih murung. Namun hingga kini, sifat tersebut menjadi seperti kebiasaan pada dirinya. Dari segi fisik, Yanda merasa menjadi lebih mudah sakit.

Mendapat insight bahwa terdapat perspektif yang lain dari perspektif miliknya. Dari perasaaannya terhadap keluarga, Yanda merasa keluarga yang seharusnya hangat, justru saat tidak ada harmonisasinya antar sesama anggota keluarga. Melihat dirinya dan ayah, Yanda merasa hubungannya berubah menjadi lebih jarang bicara pasca perceraian. Selain itu Yanda juga merasa perceraian membuat ibunya berantakan dan bingung, sebab banyak hal yang perlu dikerjakan, dari bekerja mencari uang sampai mengurus anak-anak dan rumah tanpa suami, sehingga Yanda merasa kasian pada ibu.

\section{Decision phase}

Adanya perubahan perasaan dan wawasan baru bahwa pespektif sebelumnya tidak lagi dapat bekerja. Dari kejadian penipuan yang dilakukan oleh mantan istri ayah, Yanda mulai merasa kasihan pada ayahnya sehingga dapat dikatakan bahwa Yanda cukup merasa kasihan pada ayahnya atas perceraian yang telah terjadi. Seperti yang telah dijelaskan sebelumnya bahwa salah satu penyebab perceraian orang tuanya ialah karena ayahnya ingin menikah pada wanita yang memeluk agama Islam. Namun, wanita yang dinikahi tersebut justru menipu dan merugikan ayahnya dalam bentuk material.

Kendati merasa kasihan, Yanda belum merasa perceraian orang tua bukanlah jalan yang terbaik yang bisa diambil oleh ayahnya. Bagi Yanda, ayahnya tetap tidak merasa cukup puas dengan keadaan keempat anaknya telah memeluk agama yang sama dengan dirinya, yaitu Islam. Maka dari itu, Yanda tetap merasa bahwa ayahnya bersalah.

Kesediaan untuk mempertimbangkan memaafkan sebagai pilihan. Yanda pernah berpikir untuk memaafkan ayah. Alasan Yanda ingin memaafkan ialah sebab dalam hati, ia masih menyayangi ayahnya. Selain itu juga, ayahnya tetaplah orang tuanya. Bagi Yanda, ayahnya tetaplah orang tuanya, dan surga berada ditelapak ayah dan ibunya, bukan hanya ibunya. Niat untuk memaafkan muncul sekitar dua tahun yang lalu, ketika ayahnya ditipu dan merasa sangat terpuruk. Dari kejadian itu, Yanda merasa kasian.

Dari keterangan yang diberikan, Yanda menunjukkan ia sedang pada tahap 4 memaafkan, yaitu lawfully expecational forgiveness, dimana ia perlu memaafkan sebab pelaku ialah orang tuanya sendiri. Selain itu, dengan menjelaskan bahwa surga berada di telapak ayahnya, Yanda sekali lagi menunjukkan bahwa alasan ia memaafkan karena agama yang mengajarkan bahwa ada surga di telapak kaki orang tuanya.

Berkomitmen untuk memaafkan pelaku. Setelah memutuskan untuk memaafkan, terdapat beberapa hal yang dirasakan oleh Yanda. Pertama, Yanda merasa jauh lebih bisa mengontrol emosi, dari yang sebelumnya seringkali marah, dan sering menggerutu pada diri sendiri karena terbawa stress. Selain itu, Yanda juga merasa lebih tenang dan tidak ada lagi terlalu banyak pikiran.

Mengenai hubungannya dengan ayah, Yanda merasa hubungannya baik-baik saja, meskipun ia tetap menjaga jarak. Di samping itu, dari kondisi ayahnya yang saat ini sudah menikah dengan wanita yang satu agama dengan ayahnya, sebenarnya Yanda mendapatkan insight bahwa ayahnya ingin memiliki

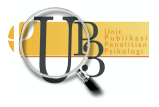


seorang pasangan yang satu agama dengannya untuk menjaganya di hari tua nanti. Hal tersebut tentu tidak bisa terjadi jika ayahnya masih bersama dengan ibu.

\section{Work phase}

Reframing. merupakan proses melalui pengambilan peran, siapakah pelaku sebenarnya, dengan melihatnya dalam konteks yang berbeda. Reframing kurang muncul pada Yanda. Yanda sendiri tidak pernah menilai perceraian dari situasi ayah sebab ia merasa ayahnya dengan mudahnya meninggalkan ibu karena ingin memiliki pasangan satu agama. Namun ketika jika diminta untuk memosisikan diri sebagai ayah, Yanda tidak akan memutuskan untuk bercerai sebab ibunya sudah rela keempat anaknya memeluk agama suami (Islam). Sedangkan, ayah masih tetap mencari kesalahan ibu.

Berempati kepada pelaku. Yanda sendiri dapat dikatakan belum berempati pada pelaku sebab reframing yang dilakukan pada tahap sebelumnya belum berhasil. Dalam tahap tersebut ia masih beranggapan bahwa keputusan untuk bercerai merupakan keputusan salah yang diambil oleh ayahnya, dan hal tersebut membuatnya merasa kesal, sehingga tidak muncul empati.

Belas kasih pada pelaku. Pada Yanda, belas kasih yang sedikit muncul ialah perasaan kasihan karena ayahnya pernah tertipu oleh mantan istrinya. Ia menjelaskan bahwa kejadian tersebut membuat ayahnya sangat terpukul dan kehilangan banyak uang. Meskipun di sisi lain, Yanda melihat saat ini ayahnya telah bahagia dengan istri yang seiman, dan dapat menjaga ayahnya di hari tua nanti.

Menerima rasa sakit. Pada Yanda sendiri, penerimaan rasa sakit atas perceraian sepertinya masih dalam proses. Yanda merasa sudah dapat menerima perceraian orang tua, meskipun melalui proses yang panjang. Sebelum akhirnya menerima, banyak pemikiran yang dimiliki Yanda, sebab dulu kedua orang tuanya terlihat bahagia. Yanda juga mengkhawatirkan kondisi adik-adiknya, juga ayahnya. Ia takut ayahnya salah lagi dalam memilih pasangan. Di sisi lain, saat ini Yanda merasa perceraian bukanlah langkah yang terbaik sebab hal tersebut membuat ibunya hancur.

\section{Deepening phase}

Menemukan makna bagi diri sendiri dan orang lain dalam penderitaan dan dalam proses memaafkan. Setelah mencoba untuk memaafkan ayah, Yanda mencoba belajar dari kesalahan dan menghargai orang yang sudah peduli dengannya, seperti ibu kepada ayahnya. Ia menggambarkan ibunya masih sangat peduli dan seringkali mengingatkan ayahnya untuk jangan sampai jatuh pada lubang yang sama.

Menyadari bahwa diri sendiri juga membutuhkan pemaafan dari orang lain di masa lalu. Keputusan Yanda untuk memaafkan ayahnya disebabkan oleh kesadaran bahwa dirirnya juga membutuhkan maaf dari orang lain. Hal ini ia rasakan ketika berbuat salah dengan ibu jika bolos sekolah. Salah satu contohnya ketika ia berpura-pura sakit agar tidak masuk sekolah, ibunya pasti merasa sedih sambil. Perasaan yang muncul ialah ialah menyesal. Kendati demikian, Yanda berpikir bahwa ayahnya tidak pernah merasa menyesal atas perbuatannya pada Yanda maupun ibu. Alasan Yanda berpikir seperti itu sebab ayahnya tidak pernah sekalipun meminta maaf pada dirinya. 
Mendapatkan insight bahwa seseorang tidak sendiri (adanya dukungan). Yanda mengaku jarang membagikan ceritanya pada orang lain, termasuk teman-temannya. Baginya, bercerita mengenai keadaan orang tuanya tidak diperlukan. Meskipun begitu, Yanda mengaku dukungan yang cukup berperan baginya selama ini ialah dukungan yang diberikan oleh temannya, yang "bernasib sama" dengannya. Selain itu, dukungan yang Yanda harapkan saat ini ialah dukungan dari ayahnya.

Mendapatkan kesadaran bahwa seseorang mungkin memiliki tujuan hidup yang baru akibat rasa sakit yang dialami. Setelah melalui proses memaafkan, Yanda mengaku tujuannya saat ini ialah untuk menyenangkan dan membanggakan ibunya, terutama dibidang akademis. Untuk melakukannya, ia berhadap dapat berprestasi, namun sulit untuk dilakukan sebab bagi Yanda, teman-teman sekolahnya saat ini kurang mendorongnya untuk semangat belajar. Yanda pun juga ingin menyenangkan ayahnya, namun ia merasa apa yang ia inginkan dan yang diharapkan ayahnya berbeda.

Adanya kesadaran akan penurunan afeksi negatif dan mungkin, peningkatan afeksi positif. Pada ayah, penurunan afeksi negatif yang dilakukan oleh Yanda ialah berusaha untuk lebih mendengarkan masukan-masukan dari ayah, meskipun terkadang kurang setuju, meskipun di samping itu, Yanda merasa tetap perlu untuk menjaga jarak, namun hubungannya baik-baik saja. Yandapun mengikuti perkataan ayah untuk meperluas pergaulan dengan siapa saja. Sedangkan peningkatan afeksi positif yang dilakukan Yanda ialah munculnya keinginan untuk bertemu dengan ayah, tidak seperti dulu. Hal ini mungkin didukung dengan perilaku ayah yang lebih sering mengontak dan menanyakan kapan akan ke rumahnya. Yanda juga mulai sesekali merasa rindu pada ayah, namun merasa tidak begitu terasa. Jika ke rumah ayah pun, Yanda memikirkan ibunya yang sendirian di rumah.

\section{Gambaran Memaafkan dalam Konteks Islam}

Yanda mengaku kurang paham bagaimana sebenarnya konsep memaafkan dalam agama Islam. Yang ia ketahui ialah memaafkan merupakan sebuah kewajiban, sebab Allah SWT adalah yang Maha Pemaaf, sehingga sebagai seorang hamba, ia merasa wajib untuk memaafkan sesama. Yanda pun juga mengetahaui bahwa memaafkan telah diajarkan Nabi Muhammad SAW sebagai akhlak yang mulia, dan memaafkan justru tidak dianggap lemah.

Meskipun mengetahui konsep memaafkan, Yanda mengaku hal tersebut tidak terlalu berpengaruh pada keputusannya untuk memaafkan. Ajaran agama Islam yang justru paling memengaruhinya untuk memaafkan ayah ialah perintah untuk menghormati dan tidak menyakiti kedua orang tua, sebab sebagaimapun orang tua bersalah, tetaplah surga berada di telapak kaki kedua orang tuanya. Ia pun menjelaskan lebih lanjut, ia tidak ingin masuk neraka hanya karena ia tidak memaafkan ayahnya. Meskipun begitu, saat ini Yanda merasa jika belum mampu mendapat pahala atas membahagiakan ayahnya, setidaknya ia tidak membuat dosa.

\section{Partisipan 2}

Dimas (bukan nama yang sebenarnya) merupakan seorang remaja laki-laki berusia 16 tahun dan saat ini sedang duduk dibangku kelas dua SMA. Dimas merupakah anak kedua dari dua bersaudara dari seorang ayah yang merupakan keturunan suku Batak, dan seorang ibu yang merupakan keturunan suku Jawa. ayah Dimas sendiri merupakan seorang wiraswasta yang memimpin perusahaannya sendiri,

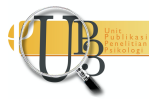


sedangkan ibu Dimas, merupakan seorang Pegawai Negeri Sipil. Kakak Dimas sendiri merupakan seorang laki-laki yang saat ini berusida 23 tahun dan sedang menempuh pendidikan di salah satu perguruan tinggi di Jakarta.

Dimas mengaku cukup dekat dengan ibu. Selain karena memang tinggal satu rumah, ia mengaku merasa nyaman berkomunikasi dan terbuka dengan ibu. Dimas merasa kurang terbuka dengan ayah, yang mungkin disebabkan karena perbedaan tempat tinggal. Dimas dan kakak sendiri secara rutin datang ke rumah ayah, kurang lebih dua minggu sekali. Sebab Dimas dan ayah jarang memberikan kabar satu sama lain, Dimas hanya mengetahui kabar ayah jika ia datang berkunjung ke rumahnya.

Mengenai ajaran agama Islam di keluarganya sendiri, Dimas menjelaskan bahwa ajaran yang diterapkan oleh kedua orang tuanya sama dengan kebanyakan keluarga lain. Dimas diajarkan untuk salat lima waktu, salat jumat, mengaji (membaca Al-Quran), berpuasa, dan berzakat. Meski demikian, Dimas mengaku ajaran yang diberikan ayahnya jauh lebih kuat dibandingkan dengan ibu.

Perceraian orang tua Dimas terjadi saat Dimas, kurang lebih, masih di taman kanak-kanak-kelas 1 SD. Pada saat ini, perceraian orang tua Dimas sudah berusia 11 tahun. Pernikahan orang tua Dimas terhitung dari menikah sampai bercerai berusia 12 tahun. Sebelum perceraian tersebut terjadi, Dimas sama sekali tidak pernah melihat atau mendengar suatu konflik serius terjadi di antara kedua orang tuanya. Hal ini mungkin terjadi sebab saat itu Dimas masih sangat kecil (6-7 tahun) sehingga belum mengerti banyak hal. Dimas pun tidak mengetahui bahwa kedua orang tuanya bercerai hingga ia berusia 12 tahun.

\section{Gambaran Umum Memaafkan}

\section{Uncovering phase}

Menelaah ulang pertahanan psikolgois diri. Defense mechanism yang Dimas gunakan bukanlah denial sebab terlihat bahwa saat pertama kali mengetahui bahwa kedua orang tuanya bercerai, Dimas justru memahami mengapa kedua orang tuanya tidak tinggal bersama selama bertahun-tahun. Kendati demikian, saat mengetahui keadannya orang tuanya, Dimas cenderung menyimpan perasaanya sendiri dan enggan membagikannya pada orang lain, bahkan pada keluarganya sendiri. Hal ini dapat dilihat sebagai bentuk represi dari Dimas.

Mengkonfrontasi rasa marah. Poin utama dari memaafkan sendiri ialah mengakui kemarahan dan mengekspresikannya dengan cara yang sesuai dan menurunkan emosi pada pelaku. Dimas sendiri mengaku merasa marah dan kesal, terlebih pada ayahnya karena dianggap semudah itu untuk meninggalkan ibu untuk menikah dengan wanita lain dan kemudian tidak ada disampingnya selama ia tumbuh, namun, Dimas mengaku tidak pernah mengungkapkannya secara langsung pada ayah. Dimas merasa lebih perasaannya ia simpan sendiri, tanpa perlu orang lain mengetahuinya. Dengan penjelasan tersebut, maka terlihat jelas bahwa Dimas belum melewati tahap ini, sebab Dimas belum mengakui kemarahan dan mengekespresikanya dengan cara yang sesuai pada ayahnya.

Mengakui rasa malu atau rasa bersalah. Dengan kondisi keluarga yang sudah bercerai dan ayahnya yang sudah menikah kembali bahkan sebelum bercerai, Dimas sama sekali tidak merasa malu ataupun merasa bersalah.

Muncul kesadaran akan kesadaran akan katarsis. Dimas menjelaskan bahwa perceraian cukup memengaruhi kepribadiannya menjadi lebih sering berdiam diri sembari merenung banyak

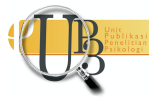


kejadian, tidak hanya perceraian orang tuanya. Hal ini mungkin muncul sebab saat kecil Dimas seringkali termenung memikirkan mengapa ia tinggal tidak tinggal bersamanya. Ia berpikir saat ini ia hanya tinggal bersama ibunya, yang seorang single parent. Hal ini cukup menguras tenaga Dimas.

Muncul kesadaran yang berulang mengenai hal yang menyakitkan. Dimas mengaku hal ini sering terjadi pada dirinya dulu, dan tidak lagi sekarang. Dimas seringkali membayangkan bagaimana jika ayah dan ibunya tidak bercerai, apa yang akan terjadi, dan bagaiman kondisi keluarganya. Selain itu Dimas juga seringkali mempertanyakan pada diri sendiri, mengapa keduanya harus bercerai. Perasaan sakit dan kaget masih muncul ketika ia membayangkan kedua orang tuanya baru memberi tahu keduanya telah bercerai saat ia telah berusia 12 tahun.

Mendapatkan insight dengan membandingkan diri dengan pelaku. Dimas mengaku seringkali melakukan hal ini dulu, terlebih saat ia masih duduk di bangku SMP. Saat itu, ia seringkali membayangkan ayahnya yang dapat semudah itu meninggalkan ibunya untuk menikah dengan wanita lain, hingga mengasuh anak dari ibu tirinya tersebut. Dimas seringkali berpikir, mengapa ayahnya tidak mengasuh anak-anaknya sendiri, tapi mengasuh seorang yang bukan anak kandungnya sendiri.

Sadar bahwa diri sendiri dapat berubah secara permanen dan negatifakibat rasa sakit tersebut. Dimas kurang mampu membedakan apakah perceraian telah merubah dirinya secara permanen dan negatif, sebab ia baru mengetahui kedua orang tuanya bercerai saat ia berusia 12 tahun, dimana Dimas merasa ia kepribadiannya sudah terbentuk dan sudah memiliki sifat tersendiri. Saat ini, Dimas juga mengaku kurang terbuka dengan orang lain, dan lebih merasa nyaman jika menyimpan rasa sakitnya sendiri. Dimas juga merasa kurang suka banyak bicara, dan seringkali canggung jika berada di depan banyak orang.

Mendapat insight bahwa terdapat perspektif yang lain dari perspektif miliknya. Ada perspektif baru pada Dimas dari rasa sakit yang ia alami. Dimas sudah merasa sangat terbiasa hidup tanpa seorang ayah. Bahkan terkadang Dimas berpikir bahwa ayahnya telah meninggal, sehingga saat ini ia tinggal tidak tinggal bersama untuk berada disampingnya. Ia berpikir saat ini ia hanya tinggal bersama ibunya, yang seorang single parent.

\section{Decision phase}

Adanya perubahan perasaan dan wawasan baru bahwa pespektif sebelumnya tidak lagi dapat bekerja. Pada tahap ini, Dimas mulai memikirkan pespektif lainnya dari perceraian orang tua. Dimas menyadari bahwa perceraian orang tuanya sudah terjadi begitu lamanya, sehingga ia tidak perlu memikirkan atau merasa kesal pada ayahnya terus-menerus hingga kini. Selain itu, saat memasuki masa SMA, Dimas mulai bepikir bahwa perceraian merupakan hal yang biasa terjadi pada rumah tangga orang lain

Kesediaan untuk mempertimbangkan memaafkan sebagai pilihan. Dimas mengaku terpikir untuk memaafkan ayahnya, meskipun sampai saat ini dirinya masih merasa kesal dan berusaha untuk bersifat masa bodoh atas perasaan kesal tersebut. Dimas merasa percerain orang taunya sudah merupakan cerita lama, dan tidak pantas untuk terus-menerus dipikirkan. Pikiran untuk memaafkannya ayahnya sendiri muncul ketika Dimas memasuki SMA, dimana Dimas mulai bepikir bahwa perceraian merupakan hal yang biasa terjadi pada rumah tangga orang lain, dengan melihat 
pengalaman teman-temannya. Selain itu, ibu Dimas juga seringkali meningatkan untuk tidak terlalu memikirkan perceraian lagi, sebab kejadian tersebut sudah berlalu di waktu yang sangat lama.

Ayah sendiri juga pernah meminta maaf pada Dimas saat dirinya duduk di bangku kelas tiga SMP. Dimas sendiri menilai 50 persen dirinya telah memaafkan ayah, dan 50 persen dirinya tidak memaafkan ayahnya. Alasan Dimas untuk mencoba memaafkan ayah ialah sebab perceraian orang tuanya sudah terjadi begitu lamanya, sehingga ia tidak perlu terus menerus merasakan sakit yang timbul karenanya. Selain itu, ibu Dimas juga seringkali mengingatkan Dimas untuk memaafkan ayah sebab perceraian sudah terjagi begitu lama, dan meminta Dimas untuk menganggap perceraian orang tua sebagai pelajaran di masa depan nanti, untuk tidak mengulangi kesalahan seperit yang orang tuanya lakukan. Alasan Dimas yang terakhir ialah sebab Dimas merasa ayahnya ialah orang tuanya sendiri, orang yang telah melahirkannya sehingga ia perlu memaafkannya.

Dari keterangan yang diberikan, Dimas menunjukkan ia sedang pada tahap 3 memaafkan, yaitu expectational forgiveness, dimana ia perlu memaafkan sebab ayah dan ibu Dimas memintanya untuk memaafkan ayah. Menurut Enright, Santos, \& Al-Mabuk (1989), pada tahap ini seseorang cenderung lebih mudah memaafkan bila orang lain mengharapkannya. Di saat yang bersamaan, Dimas juga menunjukkan ia sedang pada tahap 4 memaafkan, yaitu lawfully expectational forgiveness, dimana ia perlu memaafkan sebab pelaku ialah orang tuanya sendiri, orang yang melahirkannya. Menurut Dimas, di agama Islam, bagaimanapun orang tua tetaplah orang tua yang perlu dihormati.

Berkomitmen untuk memaafkan pelaku. Rasa sakit yang Dimas rasakan buka kepada perceraian orang tuanya, namun lebih pada ketidakhadiran pebuh ayah dalam hidup Dimas. Jika mengingat kembali masa kecil tanpa ayah, Dimas masih seringkali merasakan sakit yang begitu mendalam. Dengan kata lain, Dimas belum melewati tahap berkomitmen untuk memaafkan ayah.

\section{Work phase}

Reframing. Reframing terlihat pada Dimas. Ia mengaku, setelah ibu memberikan penjelasan bahwa dalam perceraian ini ayah dan ibu sama-sama memiliki sisi bersalah sehingga tidak pantas untuk menyalahkan satu pihak saja, Dimas mulai mencoba melihat perceraian dari sisi yang berbeda. Dimas yang dulu melihat bahwa perceraian orang tuanya merupakan salah ayah sepenuhnya, kini mulai mengerti mengapa ayahnya kecewa pada ibu, meskipun Dimas tetap tidak membenarkan atau mengompromi, namun mencoba untuk lebih mengerti.

Berempati kepada pelaku. Sebab telah melakukan reframing dengan melihat ayah dalam konteks yang berbeda, empati yang muncul pada Dimas cukup terlihat. Dengan melihat ayahnya sebagai orang tua, Dimas melihat keinginan ayahnya untuk tinggal bersama anak-anak kandungnya. Dimas mengaku, ayahnya pernah menyatakan keinginannya untuk tinggal bersama Dimas dan kakak, namun tidak bisa karena perjanjian sidang perceraian yang menyatakan bahwa hak asuh kedua anak jatuh pada ibu. ayah

Belas kasih pada pelaku. Perasaan kasihan pada Dimas muncul pada ayah ketika ayahnya meluapkan perasaan sedihnya karena tidak bisa tinggal bersama Dimas dan kakak. Perasaan kasihan juga muncul pada ibu sebab Dimas melihat ibu sebagai seorang single parent yang mencari uang dan membesarkan anak-anaknya sendiri tanpa pasangan. Selain itu, Dimas juga merasa iba sebab tahu pendapatan ibu yang tidak begitu besar, dan harus dihabiskan pada pendidikan anak-anaknya yang bersekolah di sekolah swasta. 
Menerima rasa sakit. Pada Dimas sendiri, penerimaan rasa sakit atas perceraian sepertinya telah dicapai. Dimas merasa sudah dapat menerima perceraian kedua orang tuanya, meskipun melalui proses yang panjang. Sebelum akhirnya menerima, Dimas seringkali berpikir "kenapa ya mereka harus pisah?", sebab Dimas memiliki keinginan kedua orang tuanya tinggal bersama dalam satu rumah. Hal sulit lainnya dalam menerima perceraian ialah berkurangnya intensitas pertemuan Dimas dengan ayah.

\section{Deepening phase}

Menemukan makna bagi diri sendiri dan orang lain dalam penderitaan dan dalam proses memaafkan. Dalam memaafkan ayah, Dimas menemukan makna tersendiri dalam pengalamannya. Bagi Dimas, perceraian tidak lagi perlu dipikirkan terlalu dalam, yang terpenting ialah bagaimana perceraian harus membuatnya belajar agar lebih maju. Dimas mengaku hanya ingin mengambil hal positif dari perceraian dan berusaha sebaik mungkin untuk tidak mengulangi kesalahan yang dilakukan ayahnya. Dimas mengaku sudah sangat terbiasa hidup tanpa ayah.

Menyadari bahwa diri sendiri juga membutuhkan pemaafan dari orang lain di masa lalu. Keputusan Dimas untuk memaafkan ayahnya disebabkan oleh kesadaran bahwa dirirnya juga membutuhkan maaf dari orang lain. Hal ini ia rasakan ketika berbuat salah ia perasaan tidak enak dan bersalah pada orang lain. Dalam hal ini, Dimas menyadari bahwa ayahnya juga merasakan hal yang sama, sebab ayah pernah menyatakan maaf atas kesalahannya pada dirinya dan kakak.

Mendapatkan insight bahwa seseorang tidak sendiri (adanya dukungan). Dimas mengaku tidak terlalu banyak membagi cerita perceraian orang tuanya pada orang sekitar. Dimas menekankan bahwa ia tidak menganggap penting dukungan orang lain seperti teman, orang tua, atau kakak. Dimas mengaku bisa bangkit dan mendapat dukungan dari dirinya sendiri, sebab ia merasa tidak bisa bergantung pada siapapun. Maka dengan demikian, ia tidak mengharapkan dukungan tertentu dari orang lain. Yang terpenting bagi Dimas ialah untuk belajar dari perceraian orang tuanya.

Mendapatkan kesadaran bahwa seseorang mungkin memiliki tujuan hidup yang baru akibat rasa sakit yang dialami. Dengan mencoba melewati rasa sakit yang timbul akibat perceraian orang tua, Dimas memiliki tujuan baru dalam kehidupannya. Suatu hari nanti jika ia telah menikah, ia akan berusaha untuk setia dan menerima pasangannya sebaik mungkin, sehingga langkah cerai tidak akan diambil. Selain itu Dimas juga akan berusaha menjadi ayah yang baik di keluarga, seorang ayah yang memikirkan perasaan anak-anaknya.

Adanya kesadaran akan penurunan afeksi negatif dan mungkin, peningkatan afeksi positif. Seringkali Dimas menjelaskan bahwa ia memiliki keinginan untuk pergi bersama ayah, dan hal tersebut diketahui oleh ibu. Terlebih sejak ayah didiagnosis memiliki penyakit diabetes oleh dokter, Dimas ingin lebih meluangkan waktu untuk ayahnya sambil memantau kesehatannya. Meski begitu, ibu Dimas seringkali memberi pesan untuk jangan terlalu sering bertemu dan jangan terlalu dekat dengan istri ayah, sebab istri ayah masih dianggap ibu sebagai "perusak" rumah tangga ayah dan ibu Dimas. Dari pesan yang diberikan ibu tersebut, Dimas merasa tidak enak untuk telalu sering pergi bersama ayah, sebab bertemu ayah sama dengan bertemu dengan istri ayah. 


\section{Gambaran Umum Memaafkan dalam Konteks Agama Islam}

Bagi Dimas, memaafkan dalam Islam ialah merelakan pengalaman menyakitkan yang telah terjadi tanpa menyalahkan siapapun. Selain itu, Dimas juga menjelaskan bahwa dalam Islam, memaafkan lebih baik dari pada memendam perasaan amarah dalam hati. Dimas menekankan bahwa memaafkan tidak berarti membenarkan perilaku salah dari pelaku. Dimas juga mengetahui bahwa memaafkan merupakan sebuah akhlak yang mulia dan memaafkan bukanlah sikap yang menunjukan lemah.

Meskipun mengetahui konsep memaafkan, Dimas mengaku hal yang paling memengaruhinya untu memaafkan ayah ialah ajaran Islam untuk merelakan pengalaman menyakitkan yang terjadi, sebab tidak baik memendam amarah, serta memaafkan tidak berarti memebenarkan perilaku pelaku. Bagi Dimas, hal tersebut sangat sesuai pada pengalamannya, namun pengaruhnya pun Dimas akui tidak begitu signifikan.

\section{Partisipan III}

Putra (bukan nama yang sebenarnya) merupakan seorang remaja laki-laki berusia 16 tahun dan baru saja lulus dari SMA. Putra merupakan anak ketiga dari tiga bersaudara dari seorang ayah yang merupakan keturunan Padang, dan ibu yang merupakan keturunan Gorontalo. ayah Putra sendiri merupakan seorang wiraswasta real estate, sedangkan ibu merupakan seorang pensiunan PNS (Pegawai Negeri Sipil), yang kini menjadi wiraswasta bidang properti.

Putra mengaku tidak telalu dekat dengan ibu, meskipun ia tinggal satu rumah. Ia mengaku tidak merasa terlalu nyaman berkomunikasi dan terbuka mengenai hal-hal yang personal pada ibu. Putra menjelaskan ibu seringkali menyamakan dirinya dan ayah, sebab Putra merupakan anak laki-laki satunya, dan hal tersebut membuat Putra tidak nyaman. Jika di rumah, Putra memilih untuk tinggal di kamar ketimbang harus ke ruang keluarga dan bertemu dengan ibu dan kakak. Putra juga tidak saling memberi kabar dan bertemu ayahnya sama sekali selama lima tahun kebelakang. Hal ini bermula setelah ayah dan ibunya resmi bercerai, dan ayahnya pergi dari rumah. Putra menjelaskan, dirinyalah yang memutuskan kontak dengan ayah sebab merasa begitu marah atas perceraian kedua orang tuanya.

Mengenai ajaran agama dalam keluarganya, Putra mengaku keluarganya cukup menerekapkan nilainilai yang lebih kental dibandingkan keluarga kebanyakan. Selain diajarkan untuk salat, mengaji (membaca Al-Quran), berpuasa, dan zakat, Putra diajarkan untuk memahami Bahasa Arab, agar dapat memahami betul arti dari ayat-ayat Al-Quran. Maka dari itu, orang tua Putra selalu menyekolahkan Putra pada sekolah Islam, agar Putra paham betul mengenai nilai-nilai agama Islam. Meski demikian, Putra mengaku ajaran yang diberikan oleh ibunya jauh lebih kuat dibandingkan dengan ayah. Sampai saat ini pun, ibu seringkali membangunkan Putra di pagi hari untuk salat subuh.

Saat Putra duduk di kelas 2 SMP, orang tua Putra akhirnya memutuskan untuk bercerai. Saat itu, tidak ada komunikasi khusus antara kedua orang tua pada anak-anak mengenai keputusan bercerai. Kedua orang tua Putra hanya memberi tahu, bukan meminta izin. Ayah memberi tahu kedua kakak Putra, dan ibu memberi tahu Putra. Putra tidak begitu paham mengenai pembagian peran tersebut. Yang jelas perasaan yang muncul ketika tau orang tuanya akan bercerai pada Putra ialah perasaan lega. Setelah resmi bercerai, Putra akhirnya pindah bersama ibu ke sebuah rumah yang baru saja dibeli menggunakan uang harta gono gini hasil keputusan sidang perceraian.

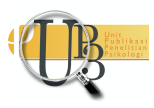


Di dalam perceraian orang tuanya ini, Putra menyalahkan ayahnya karena kurangnya tanggung jawab pada keluarga. Putra sebenarnya merasa laki-laki yang sudah menikah dan "bermain" perempuan merupakan hal yang biasa. Yang paling menyakitkan bagi Putra ialah karena hal tersebut, ayahnya melepaskan tanggung jawabnya sebagai kepala keluarga. Terlebih kebutuhan jasmani dan rohani anak yang harus terpenuhi dari sisi ayah.

\section{Gambaran Umum Memaafkan}

\section{Uncovering phase}

Menelaah ulang pertahanan psikolgois diri. Reaksi pertama saat orang tua bercerai justru sangat lega dan besyukur, sebab ia merasa sudah sangat muak jika harus terus menerus mendengar pertengkaran orang tuanya. Kendati demikian, akhir-akhir ini, Putra justru merasa kurang role model sebagai laki-laki, sebab ia merasa ayahnya bukan seorang laki-laki yang baik. Putra sangat kecewa pada ayahnya, sebab ayah tidak menjaga dan tidak bertanggung jawab pada keluarga.

Putra seringkali salat jika merasa kesal dan kusut. Baginya, salat membuatnya merasa tenang dan lega. Dalam salat tersebut ia berdoa, agar Allah SWT menjaga hubungannnya dengan ayah dan ibu, dan agar dijauhkan dari segala malapetaka. Cara Putra lain menerima sakit ialah dengan bermain musik dan menggambar. Putra menjelaskan, setelah bermain musik atau menggambar, ada perasaan lega tersendiri, padahal musik yang ia mainkan atau gambar yang ia buat tidak ada kaitannya dengan rasa sakit yang ia rasakan. Selain itu, hal yang dilakukan Putra ialah salat. Dapat terlihat bahwa saat ini, self-defense mechanism yang Putra gunakan ialah sublimasi.

Mengkonfrontasi rasa marah. Putra belum pernah sama sekali mengungkapkan rasa marahnya pada ayah, sebab sejak perceraian orang tuanya lima tahun yang lalu, ia sudah tidak pernah bertemu ayah. Berbeda dengan ayah, Putra pernah mengungkapkan rasa marahnya pada ibu. Mengakui rasa malu atau rasa bersalah. Dengan kondisi keluarga yang sudah bercerai dan ayahnya yang sudah menikah kembali bahkan sebelum bercerai, Putra sama sekali tidak merasa malu ataupun merasa bersalah.

Muncul kesadaran akan kesadaran akan katarsis Putra mengaku perceraian orang tua cukup memengaruhi aspek psikologisnya. Putra mengaku, perceraian membuatnya menjadi orang yang cenderung tidak berani, tidak percaya diri mengambil suatu langkah, dan tidak berani berhubungan khusus dengan lawan jenis, dimana ia merasa memiliki ketakutan akan mengecewakan pasangannya saat itu. Ia menjelaskannya sebagai trust issue dan trauma. Ia juga merasa takut menikah sebab takut gagal seperti ayahnya, sebab ibunya seringkali membandingkan dirinya pada ayah.

Muncul kesadaran yang berulang mengenai hal yang menyakitkan. Putra mengaku seringkali memikirkan perceraian berulang kali, namun bukan seperti reka adegan terdahulu. Yang seringkali Putra pikirkan ialah bagaimana keadaannya masih ada ayah dimana ia mungkin bermain mobil, atau otomotif bersama ayah seperti kebanyakan anak sekarang. Mendapatkan insight dengan membandingkan diri dengan pelaku. Dalam hal ini Putra merasa, sebagai anak, dirinya seperti tidak dipenuhi kebutuhan jasmani dan rohaninya oleh ayah. Ia merasa ayahnya lebih mementingkan "harga diri"-nya di mata orang lain, dengan "bermain" perempuan, dibandingkan mengasuh anakanaknya.

Sadar bahwa diri sendiri dapat berubah secara permanen dan negatif akibat rasa sakit tersebut. Putra menyadari bahwa dirinya dapat berubah secara permanen dan negatif akibat rasa sakit yang ia miliki. Putra merasa perceraian membuatnya menjadi orang yang tidak percaya diri akan keadaan

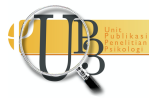


keluarganya. Dalam pertemanan Putra, terdapat momen dimana teman-temannya menceritakan keadaan ayahnya masing-masing dan seringkali membayangkan apa yang akan terjadi jika masih berasama ayahnya. Putra juga merasa memiliki trust issue untuk menjalani hubungan atau mendekati lawan jenis.

Mendapat insight bahwa terdapat perspektif yang lain dari perspektif miliknya. Sebab perceraian orang tuanya, Putra seringkali berpikir bahwa dunia merupakan tempat yang jahat. Ia seringkali berpikir mengapa hal tersebut harus terjadi pada dirinya, kenapa tidak pada anak lain. Putra ingin sekali menyahkan orang lain, namun ia tidak tahu harus menyalahkan siapa. Selain itu, saat ini Putra mengganggap pernikahan hanya sebatas ibadah saja, seperti yang diperintahkan Allah SWT dalam Al-Quran. Putra juga tidak memercayai cinta, sebab baginya cinta hanyalah fiksi. Putra merasa jauh lebih percaya pada rasa percaya dan komitmen untuk menjalankan pernikahan.

\section{Decision phase}

Adanya perubahan perasaan dan wawasan baru bahwa pespektif sebelumnya tidak lagi dapat bekerja. Putra mengaku, hal ini terjadi jelas pada dirinya setelah ia berusia 17 tahun. Sejak saat itu, ia berpikir bahwa ia merupakan anak laki-laki satu-satunya dalam keluarga, dan di dalam agama Islam, anak laki-laki memiliki tanggung jawabnya sendiri pada keluarga. Ia kemudian berpikir bahwa ia harus menjaga ayah, ibu, serta kedua kakak perempuannya. Untuk mempertanggungjawabkan hal tersebut, Putra merasa perlu terlebih dahulu berdamai dengan keadaan.

Kesediaan untuk mempertimbangkan memaafkan sebagai pilihan. Pikiran memaafkan pertama kali muncul ketika Putra berusia 17 tahun. Pada ibu, Putra merasa usianya sudah dianggap dewasa. Bagi Putra, ia memiliki tanggung jawab tersendiri pada ibu. Pada ayah, Putra merasa ayahnya masih hidup di luar sana, tanpa dirinya mengetahaui kabar ayah. Putra berpikir bahwa bagaimanapun ayahnya tetaplah orang tuanya. Dari pengalaman Putra tersebut, dapat telihat Putra menunjukkan ia sedang pada tahap 4 perkembangan memaafkan, yaitu Lawfully expecational forgiveness, dimana ia perlu memaafkan sebab pelaku ialah orang tuanya sendiri, selain itu terdapat pula ajaran agama Islam yang memengaruhi bahwa dirinya sebagai anak laki-laki satu-satunya bertanggung jawab atas seluruh anggota keluarganya.

Berkomitmen untuk memaafkan pelaku. Untuk berkomitmen pada keputusannya untuk memaafkan, Putra mencoba menyadari momen-momen dimana ayahnya peduli padanya, meskipun dari yang Putra ingat, ayahnya tidak peduli padanya. Ia mencoba membayangkan ketika ia masih kecil, ketika ia baru lahir, saat ia belum tahu menahu, ayahnya pasti memerjuangkannya. Dari pikiran tersebut, Putra berpikir bahwa bagaimanapun ayah tetaplah orang tuanya.

\section{Work phase}

Reframing: melalui pengambilan peran, siapakah pelaku sebenarnya, dengan melihatnya dalam konteks yang berbeda. Reframing nampaknya belum dilewati oleh Putra, sebab Putra masih melihat ayahnya seharusnya bertanggung jawab penuh pada keluarga dan anak-anak, bukan hanya saja mengirimkan uang, atau berada di rumah, namun memenuhi aspek secara jasmani dan rohani sekaligus. Meskipun pastinya aka nada tekanan dari pekerjaan, ayah seharusnya meluangkan waktu untuk mendidik anak. 
Berempati kepada pelaku. Sebab reframing pada ayah belum sepenuhnya dilewati, nampaknya empati tidak muncul pada diri Putra. Hal ini mungkin disebabkan ia pun sudah tidak bertemu selama lima tahun lamanya. Jika harus membayangkan perasaan ayahnya, Putra merasa ayahnya saat ini sedang sendirian, tidak tahu dengan siapa, nongkrong bersama teman-teman sebab ia sangat suka bergaul, dan rindu akan kehangatan keluarga.

Belas kasih pada pelaku. Putra merasa memiliki perasaan kasihan dan prihatin dengan ayah dan ibu, namun bagi ayah, porsinya sangat sedikit. Justru pada ibu yang lebih besar, sebab ia melihat ibunya sebagai seorang single parent yang berjuang sendiri mencari uang dan membesarkan anak. Selain itu, Putra mengganggap ibu sebagai korban dari perceraian ini, sehingga harus melakukan hal tersebut sambil menerima rasa sakit sendiri.

Menerima rasa sakit. Pada tahap ini, seseorang menyerap dan menerima kejadian yang sudah menimpannya, dan sehingga tidak melemparkan rasa sakit itu kembali kepada pelaku atau orang lain. Maka dari itu, memungkinkan rasa sakit itu untuk berhenti. Dalam hal ini, Putra merasa sangat sudah menerima perceraian orang tua. Yang ia tidak belum bisa terima ialah hilangnya figur seorang ayah dalam hidupnya. Baginya, bercerai bukan berarti hilangnya figur ayah.

\section{Deepening phase}

Menemukan makna bagi diri sendiri dan orang lain dalam penderitaan dan dalam proses memaafkan. Setelah mencoba untuk memaafkan ayah, Putra merasa lebih berani untuk mencoba hal yang baru, sebab Putra merasa menjadi lebih sedikit memikirkan banyak hal. Salah satu contohnya ialah belajar bermain piano yang ada di rumah dan tidak ada memainkan. Selain itu, Putra merasa lebih mudah untuk beradaptasi dengan lingkungan. Putra juga mengaku lebih bisa mengontrol emosinya, dibandingkan dahulu.

Menyadari bahwa diri sendiri juga membutuhkan pemaafan dari orang lain di masa lalu. Keputusan Putra untuk memaafkan ayahnya disebabkan oleh kesadaran bahwa dirirnya juga membutuhkan maaf dari orang lain. Putra mengaku merasa perlu memaafkan ayah karena ia merasa membutuhkan maaf juga dari orang lain. Bagi Putra, jika berbuat salah dengan orang lain, ada perasaan menggantung dan perasaan tidak enak di hati. Putra sendiri tidak tahu apa ayahnya merasakan hal sepeti itu, namun bagi Putra, memaafkan ia anggap sebagai hal yang sepenting itu. Jika diminta memberikan nilai, bagi Putra memaafkan memiliki nilai penting 8 (skala 1-10).

Mendapatkan insight bahwa seseorang tidak sendiri (adanya dukungan). Putra mengaku dukungan dari teman merupakan hal yang cukup membantunya melewati rasa sakit yang ia rasakan, terutama pada teman-teman yang memiliki nasib serupa. Menurut Putra, saat ini mekanisme pertahanan dirinya ialah menertawakannya, sebab ia merasa tidak ada yang bisa dirubah dari perceraian orang tuanya.

Mendapatkan kesadaran bahwa seseorang mungkin memiliki tujuan hidup yang baru akibat rasa sakit yang dialami. Pelajaran dari perceraian orang tua ialah untuk memegang sepenuhnya tanggung jawab atas segala pilihan yang ia ambil. Menurut Putra, setiap pilihan atau langkah yang seseorang ambil tentu memiliki resikonya tersendiri. Yang terpenting ialah bagaimana ia sebagai seseorang

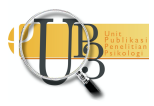


mempertanggungjawabkan pilihannya sendiri. Selain itu, Putra mengaku dewasa ini ia memiliki tujuan hidup tersendiri, yaitu untuk membanggakan orang tuanya.

Adanya kesadaran akan penurunan afeksi negatif dan mungkin, peningkatan afeksi positif. Penurunan afeksi negatif dari Putra pada ibu cukup terasa sejak Putra mengungkapkan perasannya pada ibu. Menurut Putra, sejak saat itu hubungannya dengan ibu berangsur membaik. Kemudian, peningkatan afeksi positif dari Putra pada ibu juga cukup terlihat dari bagaimana Putra berusaha untuk menjadi laki-laki seutuhnya yang diharapkan oleh ibu, yang bisa bertanggung jawab dan dapat dipercaya. Pada ayah, tidak terlihat penurunan dan peningkatan afeksi positif dari Putra. Hal ini mungkin disebabkan karena sudah 5 tahun lamanya Putra tidak bertemu atau saling bertukar kabar dengan ayah.

\section{Gambaran Umum Memaafkan dalam Konteks Islam}

Putra mengaku kurang paham bagaimana sebenarnya konsep memaafkan dalam agama Islam. Meskipun begitu, Putra mengaku hal tersebut tidak terlalu berpengaruh pada keputusannya untuk memaafkan. Ajaran agama Islam yang justru paling memengaruhinya untuk memaafkan ayah ialah bagaimana seorang anak laki-laki bertanggung jawab atas keluarga, terlebih Putra merupakan anak lakilaki satu-satunya. Dari rasa tanggung jawab tersebut, Putra merasa perlu berdamai terlebih dahulu dengan ayah dan ibunya, maka dari itu muncul keputusan untuk memaafkan.

\section{I S K U S I}

Pertama, proses memaafkan partisipan (selaku remaja) cukup berkaitan dengan kualitas hubungan dengan pelaku, seperti yang sesuai dijelaskan (Paleari dkk., 2003). Seperti yang telah dijelaskan sebelumnya bahwa kualitas hubungan partisipan Yanda dan Putra sebelum perceraian nampaknya kurang begitu baik, sedangkan kualitas hubungan pada partisipan Dimas sebelum perceraian nampak baik sehingga terdapat penurunan afeksi negatif dan afeksi positif yang lebih terlihat.

Dalam penelitian yang sama, (Paleari dkk., 2003) menjelaskan bahwa kemungkinan remaja untuk memaafkan bergantung pada ketulusan dan kerumitan alasan yang diberikan oleh pelaku. Penjelasan ini belum muncul pada penelitian ini, sebab hanya ayah Dimas yang sempat menjelaskan ketulusan dan kerumitan alasan dari keputusan bercerai pada Dimas, sedangkan tidak pada pada partisipan Yanda dan Putra, meskipun hal ini nampaknya memiliki kaitan tersendiri pada poin pertama, yaitu kualitas hubungan pelaku dengan partisipan.

Kedua, tahapan perkembangan memafkan partisipan selaku remaja ada pada di tahap 4 memaafkan, yaitu, lawfully expectational forgiveness. Hal ini tidak sesuai dengan (Enright dkk., 1989) yang menjelaskan bahwa remaja usia 15-18 tahun berada pada tahap 3 memaafkan, yaitu expectational forgiveness. Pernyataan yang muncul dari ketiga partisipan ialah "bagaimanapun ia (ayah) adalah orang tuaku" kemudian mengaitkanya dengan nilai agama. Peneliti menduga ada pengaruh budaya Indonesia pada lontaran pernyataan tersebut.

Worthington (2005) menjelaskan tiga poin utama dalam menjelaskan memaafkan dalam konteks budaya. Satu, memaafkan muncul di berbagai tingkat perkembangan manusia sebagai cara subsistem relasional berusaha untuk beradaptasi dengan konteks ekologis mereka. Subsistem ini bisa berupa individu, pasangan, keluarga, komunitas, bangsa, atau kelompok lain. Penjelasan ini cukup INSAN Jurnal Psikologi dan Kesehatan Mental 2020, Vol. 5(2), 88-111 doi: $10.20473 /$ jpkm.v5i22020.88-111

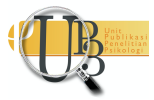


menerangkan bahwa konteks ekologi pada tingkat individu, keluarga, komunitas, bangsa, atau komunitas lain yang memasukkan partisipan sebagai bagiannya berkaitan dengan proses memaafkan itu sendiri.

Dua, lebih khusus, memaafkan merupakan salah satu cara di mana subsistem berusaha menyeimbangkan kekuatan dan kontrol dalam konteks ekosistem mereka. Maddock and Larson (1995, dalam Worthington 2005) menegaskan bahwa kekuasaan dan kontrol adalah komponen yang diperlukan dari interaksi sosial dan, jika tidak seimbang, menjadi terdistorsi dan menekan. Dari penjelasan ini dapat terlihat bahwa pemaafan orang tua oleh anak dapat dipengaruhi oleh gambaran orang tua yang lebih memiliki kuasa atau lebih mendominasi, terhadap anak, dalam keluarga.

Tiga, kontur pandangan dunia budaya individualisme dan kolektivisme mewakili seperangkat dimensi yang berbeda untuk memahami perbedaan budaya dalam model pemaafkan (Sandage \& Wiens, 2001). Budaya kolektif mengartikan kedirian sebagai saling ketergantungan dan sosial yang ditanamkan, menekankan hubungan sosial dan norma-norma kelompok. Di negara Indonesia dengan budaya kolektivis yang tinggi, pelanggaran mungkin tidak hanya terjadi pada satu orang, tetapi untuk beberapa orang. Karena itu, ketika pemaafan terjadi, itu tidak diperpanjang hanya oleh satu orang tetapi oleh keluarga, kelompok, atau kelompok lain. Pemaafan dan rekonsiliasi cenderung terkait erat atau identik dalam budaya kolektif. Tujuan pemaafan kolektif akan memrioritaskan pemulihan harmoni sosial dan kesejahteraan di atas keuntungan pribadi. Anggota masyarakat kolektivis juga cenderung memanfaatkan mediator pihak ketiga (misalnya, pemimpin keluarga atau klan) dan tokoh budaya (misalnya, pemuka agama) untuk menegosiasikan konflik dan pemaafan melalui ritual dan upacara komunal (Sandage \& Wiens, 2001).

Ketiga, pengalaman menyakitkan tiga partisipan yang perlu dimaafkan lebih berkaitan dengan apa yang dilakukan oleh pelaku sebelum atau setelah perceraian, bukan perceraian itu sendiri. Meskipun lebih berkaitan dengan yang terjadi sebelum dan/atau setelah perceraian, bukan perceraian itu sendiri, keduanya tidak bisa dipisahkan satu sama lain. Dengan demikian, ketika anak-anak dari rumah yang bercerai menunjukkan masalah, masalahnya mungkin bukan hanya karena perceraian, tetapi konflik pernikahan orang yang menuntunnya (Thompson, 2008 dalam Santrock, 2013).

Selain itu, berangkat dari penemuan tersebut, peneliti menduga ada pengaruh pola asuh orang tua dalam proses memaafkan partisipan. Dugaan ini muncul sebab pengalaman menyakitkan ketiga partisipan berkaitan dengan bagaimana ayah mengasuh partisipan. Hal ini perlu diselidiki lebih jauh, bagaimana pola asuh pada orang tua yang bercerai, dan dibandingkan, sebelum dan setelah bercerai.

Keempat, terdapat pengaruh agama Islam dalam keputusan memaafkan, namun bukan memaafkan itu sendiri. Dalam penelitian ini, peneliti hanya berfokus pada konsep memaafkan dalam agama Islam, sedangkan yang memengaruhi partisipan untuk memaafkan tidak hanya konsep memaafkan itu sendiri, melainkan konsep perilaku anak pada orang tua, dan tanggung jawab anak pada orang tua dalam agama Islam. Berangkat dari penemuan tersebut, peneliti menyadari bahwa konteks agama Islam sangatlah luas, sehingga perlu lebih berhati-hati menempatkan konteks penelitian.

Peneliti menduga kereligiusitasan partisipan cukup berkontribusi pada proses memaafkan dalam konteks agama Islam sendiri. Menurut Worthington (2005), beberapa orang mungkin termotivasi untuk memaafkan pelaku untuk melindungi hubungan mereka dengan Tuhan atau beberapa kekuatan yang lebih tinggi, yang dapat dilihat sebagai aspek yang paling disucikan dalam hidup mereka. Yaitu, keyakinan korban tentang apa yang diperlukan untuk mempertahankan ikatan langsung dengan Tuhan INSAN Jurnal Psikologi dan Kesehatan Mental 2020, Vol. 5(2), 88-111 doi: $10.20473 /$ jpkm.v5i22020.88-111

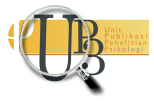


dapat mendorong proses memaafkan. Korban mungkin merasa bahwa kemarahan yang dirasakan terhadap pelaku karena merusak hadiah dari Tuhan menjadi hambatan untuk mengalami belas kasih dan pemahaman Tuhan.

Salah satu alasan yang paling penting untuk memaafkan dalam agama monoteistik adalah bahwa karena Tuhan memaafkan manusia, sehingga kita harus saling memaafkan (Rye, dkk 2000 dalam Worthington, 2005). Kegagalan untuk meniru sifat Maha Pemaaf Tuhan mungkin, dalam pikiran sebagian orang, menyebabkan kesulitan dalam hubungan seseorang dengan Tuhan. Dengan demikian, solusinya adalah melepaskan perasaan negatif terhadap pelaku tentang "penodaan" dan bahkan memperluas tindakan cinta, kasih sayang, dan kebaikan terhadap pelaku. Di sini hubungan antara korban dan Tuhan lebih diutamakan daripada hubungan korban dengan aspek-aspek kehidupan lain (Worthington, 2005).

Kelima, ketiga partisipan, secara tidak sengaja, merupakan seorang laki-laki dan menyalahkan ayah atas perceraian orang tua yang kemudian berdampak pada hilangnya figur sebagai laki-laki yang baik. Penemuan ini cukup berkaitan dengan penjelasan Bandura, Ross, \& Ross (1963, dalam Feist, Feist, \& Roberts, 2013), bahwa ketika anak-anak mengamati orang dewasa secara fisik dan verbal agresif untuk boneka bobo plastik, mereka sangat mungkin untuk mengikuti perilaku. Anak laki-laki lebih agresif secara fisik dari pada anak perempuan, namun ada sedikit perbedaan untuk agresi verbal. Anak-anak juga lebih cenderung meniru model sesama jenis.

Penelitian Bandura, Ross, \& Ross ini menunjukkan dampak yang dapat dimiliki oleh model peran berjenis kelamin sama pada anak-anak dan bagaimana pengaruhnya eksposur role model laki-laki yang baik pada anak laki-laki, yang biasa ia dapatkan pertama dari anggota keluarga terdekat, yaitu ayah. Ketika role model terdekat tidak menunjukkan perilaku baik, remaja laki-laki mungkin merasa sakit dan hal tersebut memperdalam rasa sakit yang sebelumnya ada.

Keenam, pada penelitian ini, lama waktu perceraian tidak memiliki kaitan dengan proses memaafkan partisipan. Usia percerian orang tua partisipan memiliki rentang waktu antara 5-11 tahun, dan ketiganya dalam usaha memaafkan. Hal ini mungkin terjadi karena remaja masih memutuskan untuk mempertahankan rasa sakit mereka yang mungkin berkaitan dengan kualitas hubungan partisipan dengan pelaku.

Selain itu, perceraian orang tua terjadi pada usia yang berbeda pada setiap partisipan. Pada partisipan pertama dan ketiga, perceraian terjadi pada masa remaja awal, dan pada partisipan kedua, perceraian terjadi pada masa kanak-kanak. Meski adanya perbedaan tersebut, nampaknya tidak membuat perbedaan sebab eksposur interparental yang dirasakan oleh partisipan kedua masih dirasakan hingga dirinya remaja, sehingga dengan kata lain, permasalahan orang tua masih berlangsung bahkan setelah bercerai.

\section{S I M P U L A N}

Penelitian ini bertujuan untuk menggambarkan proses memaafkan remaja yang orang tuanya bercerai dalam konteks agama Islam. Hasil penelitian menggunakan menunjukkan setiap partisipan mengalami keeempat fase dari proses memaafkan. Pertama, uncovering phase. Ketiga partisipan nampaknya menggunakan self-defense mechanism yang berbeda-beda. Meski demikian, ketiganya masih memilih untuk mempertahankan rasa marah dan sakit yang terlihat dari pernyataan masih merasa marah pada

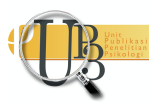


ayah, namun belum pernah mengungkapkan dengan cara yang sesuai. Ketiga partisipan juga cukup menghabiskan banyak energi untuk mencari solusi dari rasa sakit yang dialami.

Ketiga partisipan juga sempat berulang-ulang memikirkan perceraian orang tuanya, namun sudah tidak lagi dilakukan. Kemudian, ketiga partisipan mendapatkan insight dengan membandingkan diri dengan ayah, yaitu ayah yang semudah itu memutuskan untuk bercerai, sedangkan partisipan dan anggota keluarga lain diletakkan pada kondisi yang menyakitkan. Ketiga partisipan juga merasa perceraian berdampak cukup negatif pada diri mereka. Setelah melewati beberapa tahap, ketiga partisipan memiliki perspektif baru, dimana dunia adalah tempat yang tidak aman dan tidak adil.

Kedua, decision phase. Pertama-tama partisipan merasakan perubahan perasaan dan wawasan baru bahwa pespektif sebelumnya tidak lagi dapat bekerja, yaitu mempertahankan rasa sakit. Perubahan tersebut memunculkan kesediaan untuk mempertimbangkan memaafkan sebagai sebuah pilihan, yang dipengaruhi ajaran agama Islam, dan menunjukkan tahap 4 perkembangan memaafkan: lawfully expectational forgiveness. Selanjutnya muncul komitmen untuk memaafkan ayah, yang berfokus pada meninggalkan perasaan sakit hati dan komplikasi yang menyertainya, yang nampaknya belum sepenuhnya dilakukan sebab ketiga partisipan merasa masih sulit untuk menerima perasaan sakit hati yang ditimbulkan oleh ayah.

Ketiga, work phase. Partisipan melakukan reframing pada ayah melalui pengambilan peran, siapkah ayah dengan melihatnya dalam konteks yang berbeda, yang nampaknya belum dilewati oleh ketiga partisipan. Kemudian masuk pada tahap berempati kepada ayah. Menurut Enright dkk., (1998), hasil dari reframing pada tahap sebelumnya ialah pemahaman, bukan memaafkan, yang ditunjukkan dengan munculnya empati pada pelaku. Sebab reframing ketiga partisipan belum dilewati, empati pun belum terlihat begitu muncul. Setelah berempati, munculah kesadaran belas kasih terhadap ayah, meskipun kadarnya berbeda-beda, akibat melihat ayah yang berada dalam posisi yang tidak mengenakan. Terakhir, penerimaan rasa sakit. Ketiga partisipan merasa sudah dapat menerima perceraian orang tua, namun tidak yang terjadi sebelum dan/atau setelahnya.

Keempat, deepening phase. Ketiga partisipan berhasil menemukan makna bagi diri sendiri dan orang lain dalam penderitaan dan dalam proses memaafkan. Ketiga partisipan juga menyadari bahwa diri juga membutuhkan pemaafan dari orang lain di masa lalu, sehingga mendorong untuk memaafkan ayah. Selain itu, ketiga partisipan menyadari bahwa seseorang tidaklah sendiri karena adanya dukungan dari lingkungan yang datang dari teman-teman terdekat. Ketiga partisipan juga mendapatkan kesadaran akan memiliki tujuan hidup yang baru akibat rasa sakit yang dialami, yang secara garis besar, ialah untuk menyenangkan orang tua. Terakhir, kesadaran akan penurunan afeksi negatif dan peningkatan afeksi positif terlihat berbeda-beda pada setiap partisipan.

Terdapat beberapa hal yang berkaitan dengan keterbasan metodologi penelitian yang peneliti anggap menarik untuk didiskusikan. Pertama, Enright dkk., (1998)telah menurunkan empat fase memaafkan menjadi dua puluh indikator sebagai tahapan memaafkan. Beberapa dari indikator tersebut memiliki judul yang serupa, yang awalnya membuat peneliti sedikit kesulitan membedakan beberapa indikator dengan indikator yang lainnya. Maka dari itu peneliti perlu teliti dan berhati-hati membaca penjelasan dari setiap indikator. Kedua, peneliti memiliki latar belakang yang sama, yaitu orang tua yang bercerai. Hal ini dapat menimbulkan beberapa bias terhadap peneliti sendiri. Selain itu, peneliti juga menjelaskan kepada partisipan adanya kesamaan latar belakang, sehinga kemungkinan memengaruhi cara partisipan menjawab pertanyaan wawancara, khususnya saat menceritakan kesulitan menerima 
perceraian orang tua. Ketiga, tempat dilakukannya wawancara merupakan tempat umum, sesuai dengan permintaan partisipan, sehingga peneliti rasa suasananya ikut memengaruhi. Peneliti menduga bahwa hasil wawancara mungkin berbeda jika wawancara dilakukan di ruangan tertutup dan hanya melibatkan partisipan dan peneliti.

Dalam penelitian ini, terdapat beberapa hal yang menurut peneliti dapat dilakukan untuk mengembangkan penelitian selanjutnya, yaitu:

1. Data yang diambil dari penelitian ini bersifat retrospektif, atau data yang sifatnya sudah berlalu. Sifat data ini membuat partisipan perlu untuk mengingat kembali pengalaman dan informasi masa lampau. Maka dari itu, keterangan yang diberikan sangat mungkin tidak sepenuhnya sesuai dengan kejadian yang sebenarnya, atau biasa disebut recall bias dan dapat menjadi salah satu faktor yang memengaruhi kredibilitas pengelitian. Peneliti selanjutnya perlu melakukan antisipasi kemungkinan recall bias yang terjadi.

2. Penlitian ini diuji validitas menggunakan metode member checking dengan partisipan utama sebagai penguji validitas itu sendiri, oleh karena itu, kredibilitas data mengenai pengalaman lampau mengenai kejadian perceraian orang tua mungkin terpengaruh.

3. Perceraian sudah merupakan topik yang sangat sensitif, ditambah dengan mengaitkannya dengan konteks agama Islam. Maka dari itu, peneliti selanjutnya harus sangat berhati-hati menanyakan pertanyaan dalam sesi wawancara.

4. Penelitian ini hanya berfokus pada konsep memaafkan dalam agama Islam, sedangkan yang berkontribusi dalam memaafkan partisipan tidak hanya konsep memaafkan, namun banyak ajaran lain dalam agama Islam. Peneliti selanjutnya perlu berhati-hati menempatkan konteks, sebab agama Islam memiliki ajaran yang luas.

\section{UCAPAN TERIMA KASIH}

Penulis mengucapkan terima kasih pada Temu Ilmiah Nasional Himpunan Psikologi Indonesia di Bandung, 7-8 September 2018 yang telah memberikan kesempatan bagi penulis untuk mempresentasikan artikel ini.

\section{DEKLARASI POTENSI TERJADINYA KONFLIK KEPENTINGAN}

Ariadne A. Trianggono dan Danny I. Yatim tidak bekerja, menjadi konsultan, memiliki saham, atau menerima dana dari perusahaan atau organisasi manapun yang akan mengambil untung dari naskah ini, dan telah mengungkapkan bahwa ia tidak memiliki afiliasi selain yang disebut di atas.

\section{PUSTAKA ACUAN}

Amato, P. R. (1993). Children's adjustment to divorce: Theories, hypotheses, and empirical support. Journal of Marriage and The Family, (55), 23-38.

Corsini, R. J. (2010). Encyclopedia of Psychology 4th Edition. Wilwy Interscience Publication.

Creswell, J. C. (2012). Education Research, Planning, Conducting and Evaluating Quantitative and Qualitative Research 4th edition. Boston: Pearson.

Creswell, J. W. (2007). Qualitative inquiry and research design: Choosing among five traditions. Thousand Oaks: SAGE Publications Ltd.

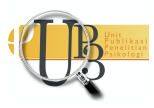


Dewi, M. (2006). Gambaran Proses Memaafkan pada Remaja yang Orang Tuanya Bercerai. Jurnal Psikologi, 4(1). Retrieved from http://digilib.esaunggul.ac.id/public/UEU-Journal-4973MestikaDewi.pdf

Enright, R. D., Freedman, S., \& Rique, J. (1998). Exploring forgiveness. London: University of Wisconsin Press.

Enright, R. D., Santos, M. J., \& Al-Mabuk, R. (1989). The adolescent as forgiver. Journal of Adolescence, 12, 95-110.

Feist, J., Feist, G., \& Roberts, T. (2013). Theories of personality. Maidenhead: McGraw-Hill.

McCullough, M. E., Worthington, E. L., \& Rachal, K. C. (1997). Interpersonal forgiving in close relationships. Journal of Personality and Social Psychology, 73, 321-336.

Muntafi, M. S. (2014). Forgiveness ditinjau dari kepribadian big five pada mahasiswa UIN Maliki Malang. Universitas Islam Negeri Maulana Malik Ibrahim. Retrieved from http://etheses.uinmalang.ac.id/617/6/10410005 Bab 2.pdf

Paleari, F. G., Regalia, C., \& Fincham, F. D. (2003). Adolescents' willingness to forgive their parents: An empirical model. Parenting: Science and Practice, 3(2), 155-174. Retrieved from http://psycnet.apa.org/record/2003-06060-005

Sandage, S. J., \& Wiens, T. W. (2001). Contextualizing models of humility and forgiveness: A reply to Gassin. .. Journal of Psychology and Theology, 29, 201-211.

Santrock, J. W. (2013). Adolescence. New York: McGraw-Hill Education.

Setyawan, I. (2007). Membangun pemaafan pada anak korban perceraian. Retrieved from http://eprints.undip.ac.id/19069/1/imam_s-_MEMBANGUN_PEMAAFAN_PADA...pdf

Toussaint, L. L., Worthington, E. L., \& Williams, D. R. (2015). Forgiveness and health: Scientific evidence and theories relating forgiveness to better health. Dordrecht: Springer.

Worthington, E. L., \& Drinkard, D. T. (2000). Promoting reconciliation through psychoeducational and therapeutic interventions. Journal of Marital and Family Therapy, 26, 93-101.

Worthington, J. E. (2005). Handbook offorgiveness. New York: Routledge Taylor \& Francis Group. 